\section{THE NECESSARY PROTAGONISM IN HOSPITAL RADIOPHARMACY}

Rua Vergueiro, $1855-12^{\circ}$ andar

Vila Mariana - São Paulo - SP

CEP 04101-000 - Tel./Fax: (11) 5083-4297

atendimento@sbrafh.org.br/www.sbrafh.org.br

Conselho Diretor

Presidente - Maely Peçanha Favero Retto

Vice-Presidente - Vandré Mateus Lima

\section{Priscilla Brunelli Pujatti}

Radiopharmaceuticals are agents that contain a radioactive atom in their structure. They are composed of a binder ("drug" portion), determinant of its biological distribution, and by a radioisotope ("radio" portion), which determines its application in nuclear medicine - whether diagnostic or therapeutic. In addition to applicability, they may vary in pharmaceutical form, quantity and quality of the radiation emitted, as well as in the route of administration employed. ${ }^{2}$

Production and commercialization of radiopharmaceuticals in Brazil began in 1959, with the production of sodium iodide-131 ( $\left.\mathrm{Na}^{131 \mathrm{I}}\right)$ by the Institute of Energy and Nuclear Research (IPEN, SP) for diagnosis and therapy of thyroid diseases. Already in the 80's, national production of Molybdenum-99/ Technetium-99m generators (Generator of ${ }^{99 \mathrm{~m}} \mathrm{Tc}$ ) was initiated at the same institute and, in parallel, the development of various lyophilized reagents for labeling with ${ }^{99 \mathrm{~m}} \mathrm{Tc}^{2}$. The physical properties of ${ }^{99 \mathrm{~m}} \mathrm{Tc}$, as well as the possibility of producing different radiopharmaceuticals from it within hospital radiopharmacy, consecrated this radioisotope as the most used in nuclear medicine and were the reasons why, for many years, more than $90 \%$ of the procedures performed in hospital radiopharmacy involved radiopharmaceuticals of ${ }^{99 \mathrm{~m}} \mathrm{Tc}^{3}$

This reality has gradually changed since the early 2000s with the emergence of positron emission computed tomography (PET-CT) and the first radiopharmaceutical for this application - fluorodeoxyglucose${ }^{18} \mathrm{~F}\left(\mathrm{FDG}^{18} \mathrm{~F}\right.$ ), half-life radiopharmaceutical 109 minutes, produced in industrial radiopharmacies or PET centers. ${ }^{4}$ The doors were opened for the greatest contribution of radiopharmacy in oncology, with the capacity for biochemical-functional diagnosis and, later, therapy with receptor-specific radiopharmaceuticals. More recently, this revolution has gained new chapters, with the introduction of the Germanium-68/Gallium-68 generator (Generator of ${ }^{68} \mathrm{Ga}$ ) in the market, allowing the production of PET radiopharmaceuticals within hospital radiopharmacy, as was the case with radiopharmaceuticals of ${ }^{99 \mathrm{~m}} \mathrm{Tc}^{5}$

The evolution of radiopharmaceuticals has modified the practices in hospital radiopharmacy, the pertinent legislation and, consequently, the activity of the pharmacyst in the area. In Brazil, the growth in the use of FDG ${ }^{-18} \mathrm{~F}$ and the continental dimensions of our country led to the breakdown of the Union monopoly on the production of radioisotopes with a half-life of less than two hours, through the Proposed Constitutional Amendment (PEC) 49/2006. Subsequently, the National Agency of Sanitary Surveillance (ANVISA) established good practices in the manufacture of radiopharmaceuticals through RDC 63 (2009), complementary to RDC 17 (2010). In addition, it regulated the registration of radiopharmaceuticals through RDC 64 (2009), recently updated by RDC 263 (2019). As a result, radiopharmaceuticals are now considered medicines, ceasing to be the exclusive subject of the National Nuclear Energy Commission (CNEN) and officially becoming part of the pharmaceutical universe. From a professional point of view, the Federal Council of Pharmacy (CFF) monitored the progress of legislation and regulated the performance of the pharmacyst in this area by Resolution CFF 486 (2008), which was recently updated with the minimum professional training requirements by Resolution CFF 656 (2018). Despite the regulatory advance, the training of the pharmacist focused on radiopharmacy during graduation is still insufficient and, despite the requirement of experience, postgraduate or free course to professional practice in the area, there are also few agents and training centers at the postgraduate level.

In the pharmaceutical context, radiopharmacy is traditionally known as a technical area when in fact it is present in most clinical specialties, offering diagnostic and / or therapeutic radiopharmaceuticals ${ }^{6}$. More specifically, hospital radiopharmacy is directly linked to a nuclear medicine service, where direct contact with the patient is inevitable and necessary. In this environment, more than a regulatory requirement, the professional needs to be recognized as an integral part of the process and, for that, its performance cannot be limited to transforming raw materials into radiopharmaceuticals and performing quality control. It is necessary to create tools to investigate nonconformities, to allow the traceability of dispensed radiopharmaceuticals and to monitor adverse events, with a focus on patient safety. Particularly with regard to short-lived PET radiopharmaceuticals, it is necessary to ensure compliance with good manufacturing practices in the in house production routine. Already in radiopharmaceutical therapy, it is fundamental to adopt a follow-up routine of the patients, developing activities regarding the clinical pharmacy and monitoring the effectiveness of the

\section{Conselho Editorial RBFHSS}

Editora-Chefe - Profa. Dra. Elisangela da Costa Lima -Dellamora - UFRJ, RJ, Brazil

\section{Editores Associados}

Profa. Dra. Angelita Cristine Melo - UFSJ - MG, Brazil Prof. Dr. Andre de Oliveira Baldoni - UFS J MG, Brazil Prof. Dr. Leonardo Regis Leira Pereira - USP-RP SP, Brazil Profa. Dra Luciane Cruz Lopes - UNISO, SP, Brazil Profa. Dra. Maria Rita Garbi Novaes - ESCS/

FEPECS, Brasilia, Brazil

Profa. Dra. Vera Lucia Luiza - ENSP/Fiocruz, RJ, Brazil

\section{Membros do Conselho Editorial}

Prof.Dr. Adriano Max Moreira Reis - UFMG, MG, Brazil Prof. Dr. Ahmed Nadir Kheir - Qatar University, Doha, Qatar Prof.Dr. Alberto Herreros de Tejada - Majadahonda, Spain Profa. Dra. Carine Raquel Blatt - UFCSPA, RS, Brazil Profa. Dra. Claudia Garcia Osorio de Castro ENSP/ Fiocruz, RJ, Brazil

Prof. Dr. David Woods - University of Otago, New Zealand

Profa. Dra. Dayani Galato - UnB, Brasilia, Brazil

Prof. Dr. Divaldo Pereira Lyra Junior - UFS, SE, Brazil Prof. Dr. Eduardo Savio - Montevideo, Uruguay Profa. Dra. Helena Lutescia Luna Coelho, UFC, CE, Brazil Profa. Dra. Inés Ruiz Álvarez - Universidad de Chile, Chile Prof. Dr.João Carlos Canotilho Lage, Coimbra, Portugal Profa. Dra. Lúcia de Araújo Costa Beisl Noblat- UFBA, BA, Brazil

Profa. Dra. Marcela Jirón Aliste, Universidad de Chile, Chile Prof. Dr. Marcelo Polacow Bisson, Sao Paulo, SP, Brazil Profa. Dra. Maria Teresa Ferreira Herdeiro, Universidade de Aveiro, Portugal

Prof. Dra. Marta Maria de França Fonteles UFC, CE, Brazil Profa. Dra. Selma Rodrigues de Castilho, UFF, Brazil Profa. Dra. Sonia Lucena Cipriano, Sao Paulo, SP, Brazil Diagramação:Liana de Oliveira Costa

\section{Missão}

Publicar artigos científicos que contribuam para o avanço do conhecimento da Farmácia Hospitalar e da assistência farmacêutica nos demais serviços de saúde, que apresentem tendências conceituais, técnicas, sociais e políticas que poderão ser utilizadas para fundamentar açōes dos profissionais da área Os artigos serão avaliados por, no minimo, dois consultores com expertise e producao científica na área de conhecimento da pesquisa.

Periodicidade: Trimestral

Exemplares: 3.000

Acesso aberto pelo website http:// www.sbrafh.org. $\mathrm{br} / \mathrm{rbfhss}$ /index/edicoes/

Circulação é gratuita para os associados da SBRAFH.

Outros interessados em assinar a revista poderão

efetuar seu pedido junto à Secretaria da SBRAFH

- Telefone: (11) 5083-4297 ou pelo e-mail: atendimento@sbrafh.org.br.

Valores para assinaturas anuais (4 edições):

- Brasil: R\$200,00

- Exterior: U\$ 150

As normas para publicação de artigos técnicos estão na página principal.

Os artigos devem ser enviados através deste site após criar seu cadastro de autor e confirmá-lo através de email enviado. Os artigos assinados são de inteira responsabilidade de seus autores e não refletem necessariamente a opinião da Sociedade Brasileira de Farmácia Hospitalar e Serviços de Saúde.

Os anúncios publicados também são de inteira responsabilidade dos anunciantes.

Esta Revista é impressa com apoio cultural do Laboratório Cristália de Produtos Químicos Farmacêuticos LTDA. 
therapy. It is necessary to assume the leading role and make the difference as a health professional, acting in strengths of pharmaceutical training, in addition to technical training. In addition, professionals working in the field must be active agents in the training of new professionals. Only with this role will we be able to permeate all aspects of the production of radiopharmaceuticals in hospital radiopharmacy, (i) from teaching to professional activities, (ii) from preparation to clinical applications and (iii) from research to commercialization, in order to follow the current legislation and to make it an instrument of transformations in the area. And only then will we have professionals, technological innovations and regulatory agents acting together and for the benefit of the community.

Priscilla Brunelli Pujatti is pharmacist, PhD in Nuclear Technology, Radiopharmacy technologist at Instituto Nacional de Câncer José Alencar Gomes da Silva (INCA/MS) and coordinator of Technical group of Hospital Radiopharmacy of SBRAFH. She is a researcher at Faculdade de Medicina de Barbacena and she is a teacher at Multidisciplinary Residency Program in Oncology (INCA).

\section{REFERENCES}

1. Sandeep Sharma, Ashish Baldi, Rejesh K. Singh, Rakesh Kumar Sharma. Regulatory framework of radiopharmaceuticals: current status and future recommendations. RJLBPCS. 2018;4(3):275-90.

2. Araújo EB de, Lavinas T, Colturato MT, Mengatti J. Garantia da qualidade aplicada à produção de radiofármacos. Revista Brasileira de Ciências Farmacêuticas. março de 2008;44(1):1-12.

3. Papagiannopoulou D. Technetium-99m radiochemistry for pharmaceutical applications. J Labelled Comp Radiopharm. 2017;60(11):502-20.

4. Olivas Arroyo C. Radiopharmaceuticals in positron emission tomography: present situation and future perspectives. Radiologia. dezembro de 2016;58(6):468-80.

5. Kolenc Peitl P, Rangger C, Garnuszek P, Mikolajczak R, Hubalewska-Dydejczyk A, Maina T, et al. Clinical translation of theranostic radiopharmaceuticals: Current regulatory status and recent examples. J Labelled Comp Radiopharm. 11 de fevereiro de 2019;

6. Ballinger JR. Hospital Radiopharmacy in the UK. In: McCready R, Gnanasegaran G, Bomanji JB, organizadores. A History of Radionuclide Studies in the UK: 50th Anniversary of the British Nuclear Medicine Society [Internet]. Cham (CH): Springer; 2016 [citado 28 de fevereiro de 2019]. Disponível em: http://www.ncbinlm.nih.gov/books/NBK500225/

\section{Corresponding Author:}

Priscilla Brunelli Pujatti pbrunelli@inca.gov.br.

How to cite this article:

Pujatti PB. The necessary protagonism in hospital radiopharmacy. Rev Bras Farm Hosp Serv Saude, 9(4): 1-2, 2018

Doi: $10.30968 /$ rbfhss.2018.094.001 